\title{
The Properties of Novel Mesophilic Denitrifying Bacillus Cultures Found in Tropical Soils
}

\author{
By FRANCIS PICHINOTY, ${ }^{1}$ MANLEY MANDEL ${ }^{2}$ \\ AND JEAN-LOUIS GARCIA ${ }^{3}$ \\ ${ }^{1}$ Laboratoire de Biochimie Végétale, U.E.R. Scientifique de Luminy, \\ 13288 Marseille, Cédex 2, France \\ ${ }^{2}$ Department of Biology, University of Texas System Cancer Center \\ M. D. Anderson Hospital and Tumor Institute Texas Medical Center, \\ Houston, Texas 77030, U.S.A. \\ ${ }^{3}$ Laboratoire de Microbiologie, O.R.S.T.O.M., Dakar, Senegal
}

(Received 18 December 1978; revised 23 April 1979)

\begin{abstract}
Fifteen endospore-forming, mesophilic, denitrifying cultures were isolated from tropical soil samples by anaerobic enrichment culture in peptone medium containing nitrite. The cultures are of the second morphological group of the genus Bacillus and contain $39 \cdot 1$ to $41.5 \mathrm{~mol} \% \mathrm{GC}$ in their DNA. They are, however, phenotypically quite heterogeneous and differ from all previously described Bacillus species. Seven of the new isolates can grow anaerobically with nitric oxide as the terminal electron acceptor, a character not previously observed in any bacterium.
\end{abstract}

\section{INTRODUCTION}

Endospore-forming denitrifying bacteria can be isolated from soils by anaerobic enrichment in peptone media fortified with $\mathrm{NO}_{3}^{--}, \mathrm{NO}_{2}^{-}$or $\mathrm{N}_{2} \mathrm{O}$. The species selected depends on the nature of the terminal electron acceptor supplied. Media of high salinity with $\mathrm{KNO}_{3}$ favour the isolation of Bacillus licheniformis because of its high osmotic tolerance (Pichinoty, 1973; Verhoeven, 1952). However, this species, which belongs to morphological group I (Gordon et al., 1973), cannot use $\mathrm{NO}_{2}{ }^{-}$or $\mathrm{N}_{2} \mathrm{O}$ as electron acceptor under anaerobic conditions; moreover, it generally produces only small quantities of $\mathrm{N}_{2}$ in peptone medium containing $\mathrm{NO}_{3}{ }^{-}$, and some strains do not produce gas after $8 \mathrm{~d}$ incubation at 32 or $40^{\circ} \mathrm{C}$ (Pichinoty et al., 1978 b).

We have introduced new selective methods to determine whether there are Bacillus species having high denitrifying activity. By using $\mathrm{N}_{2} \mathrm{O}$ instead of $\mathrm{NO}_{3}^{-}$, we have already isolated a new species, Bacillus azotoformans, which belongs to morphological group II (Gordon et al., 1973) and which vigorously reduces $\mathrm{NO}_{3}^{-}, \mathrm{NO}_{2}{ }^{-}$and $\mathrm{N}_{2} \mathrm{O}$ (Pichinoty et al., $1978 a$ ). We now describe bacteria isolated in the presence of $\mathrm{KNO}_{2}$, that also belong to group II but are clearly different from $B$. azotoformans; some preliminary results have already been published (Pichinoty et al., 1978c) describing the utilization of NO as terminal electron acceptor by some bacteria and this character has been looked for in numerous denitrifying bacteria.

This work is of some ecological interest as present knowledge of the denitrifying flora of tropical regions is meagre. All the soils used came from rice fields in Senegal which are particularly favourable environments for denitrification (Broadbent \& Clark, 1965). 


\section{METHODS}

Reference bacterial strains. The following denitrifying bacteria were used: 2 Pseudomonas aeruginosa strains from the Collection of the Pasteur Institute; Pseudomonas fluorescens strain 108 belonging to biotype B (Stanier et al., 1966); strain 229 (Stanier et al., 1966) and 12 other strains of Pseudomonas stutzeri (Pichinoty et al., 1977 c); strain 291-75 related to Pseudomonas pickettii (Garcia et al., 1977); strain 301-75 related to Pseudomonas lemoignei (Pichinoty et al., 1977d); 7 Alcaligenes denitrificans strains and 4 Alcaligenes odorans strains (Pichinoty et al., 1978d); 6 Paracoccus denitrificans strains (Pichinoty et al., 1977b); 2 Agrobacterium strains (Pichinoty et al., 1977a); Flavobacterium strain 12-75 (Pichinoty et al., 1976a); 15 B. licheniformis strains (Pichinoty et al., 1978 b); 17 B. azotoformans strains (Pichinoty et al., 1978a).

Soils. Soil samples came from Senegalese rice fields located mainly in two regions, the Casamance in the south and the river region in the north. Samples were air-dried then sifted before use, some having been stored for several years in the laboratory. Table 1 indicates the origin of each sample.

Isolation. Flasks $(250 \mathrm{ml})$ containing $50 \mathrm{ml}$ medium I (see below) were inoculated with $1 \mathrm{~g}$ soil and incubated in vacuo at $32^{\circ} \mathrm{C}$; after 3 to $5 \mathrm{~d}$, bubbles of $\mathrm{N}_{2}$ appeared in the liquid and the $\mathrm{NO}_{2}{ }^{-}$disappeared. Flasks that did not show abundant gas production were discarded. Plates of nutrient agar were then streaked and incubated aerobically at $32{ }^{\circ} \mathrm{C}$ for $48 \mathrm{~h}$. Colonies were transferred to tubes of peptone broth (Difco) containing $0.5 \%(\mathrm{w} / \mathrm{v}) \mathrm{KNO}_{3}$. Gas production was noted using inverted vials within the tubes and successive passages were made to select individual isolates with active denitrification capacity. Cultural purity was verified by colonial uniformity and by microscopic examination.

Media. The basal mineral medium contained (per litre): $\mathrm{Na}_{2} \mathrm{HPO}_{4} .12 \mathrm{H}_{2} \mathrm{O}, 3.575 \mathrm{~g} ; \mathrm{KH}_{2} \mathrm{PO}_{4}, 0.98 \mathrm{~g}$; $\mathrm{MgSO}_{4} .7 \mathrm{H}_{2} \mathrm{O}, 0.03 \mathrm{~g} ; \mathrm{NH}_{4} \mathrm{Cl}, 0.5 \mathrm{~g}$; trace metal solution (Pichinoty et al., 1977d), $0.2 \mathrm{ml} ; \mathrm{pH} 7 \cdot 0$. To the above basal medium the following additions were made (per litre). Medium I: nutrient broth (Difco), $8 \mathrm{~g}$; yeast extract (Difco), $5 \mathrm{~g} ; \mathrm{KNO}_{2}, 5 \mathrm{~g}$. Medium II: Bacto-peptone (Difco), $1 \mathrm{~g}$; yeast extract (Difco), $0.5 \mathrm{~g}$; glucose (sterilized separately at $110^{\circ} \mathrm{C}$ ), $5 \mathrm{~g}$. Medium III: nutrient broth (Difco), 8 g; yeast extract (Difco), $5 \mathrm{~g}$; Bacto-tryptone (Difco), $5 \mathrm{~g}$; L-asparagine, $2 \mathrm{~g}$ (or sodium acetate, $4 \mathrm{~g}$ ); pH 8.0, adjusted with $1 \mathrm{~m}-\mathrm{NaOH}$. Medium IV: Casamino acids (Difco), $10 \mathrm{~g}$; Bacto-tryptone (Difco), $10 \mathrm{~g}$; sodium acetate, $5 \mathrm{~g}$; biotin, $50 \mu \mathrm{g}$; folic acid, $0.1 \mathrm{mg}$; riboflavin, $5 \mathrm{mg}$; thiamin, $25 \mathrm{mg}$; nicotinic acid, $25 \mathrm{mg}$; pyridoxine, $25 \mathrm{mg}$; calcium pantothenate, $25 \mathrm{mg}$; L-tryptophan, $100 \mathrm{mg}$; DL-threonine, $100 \mathrm{mg}$; cystine, $10 \mathrm{mg}$; pH 8.0 , adjusted with $1 \mathrm{M}-\mathrm{NaOH}$. Medium V: yeast extract (Difco), $5 \mathrm{~g}$; Biotrypcase (Bio-Mérieux), $10 \mathrm{~g}$; $\mathrm{KNO}_{3}$ or $\mathrm{KNO}_{2}, 5 \mathrm{~g}$. Medium VI: nutrient broth (Difco), $8 \mathrm{~g} ; \mathrm{KNO}_{3}, 5 \mathrm{~g}$. Medium VII: yeast extract (Difco), $4 \mathrm{~g}$.

Gases. $\mathrm{N}_{2}, \mathrm{~N}_{2} \mathrm{O}$ and $\mathrm{NO}$ were of the purest grade from 'L'Air Liquide'.

Morphology. For measuring cells and spores, wet mounts were prepared from $5 \mathrm{~d}$ cultures grown on nutrient agar at $32{ }^{\circ} \mathrm{C}$. Flagella were stained by the technique of Rhodes (1958). Capsules were observed in India ink preparations. Cells cultured in medium VII containing $2 \%(\mathrm{w} / \mathrm{v})$ sodium DL-3-hydroxybutyrate were examined after staining with Sudan Black for the presence of poly- $\beta$-hydroxybutyrate. Confirmation of the absence of the latter was obtained by the method of Law \& Slepecky (1961).

Extraction of an intracellular pigment. A 71 fermenter culture was grown aerobically at $32{ }^{\circ} \mathrm{C}$ in $0.4 \%$ $(\mathrm{w} / \mathrm{v})$ yeast extract (Difco) plus 0.2\% (w/v) Proteose-peptone (Difco) for $7 \mathrm{~h}$. Exponential phase cells were harvested by centrifuging, washed and lyophilized. The yellow pigment was extractable with cold methanol but not with ethanol, acetone, benzene, petroleum ether or carbon tetrachloride. Methanol was removed in vacuo.

Diagnostic tests. All tests were carried out at $32^{\circ} \mathrm{C}$. The following tests were performed as described by Skerman (1967): gelatin liquefaction, hydrolysis of Tween 80, Voges-Proskauer reaction and urease production. The following tests were done as described by Gordon et al. (1973): tyrosine decomposition, deamination of phenylalanine, production of indole and of dihydroxyacetone, hydrolysis of hippurate and of starch, pigmentation from glucose and tyrosine, $\mathrm{NO}_{3}{ }^{-}$reduction to $\mathrm{NO}_{2}{ }^{-}$, growth in the presence of azide, growth at $\mathrm{pH} 5 \cdot 6$, lysozyme resistance, $\mathrm{NaCl}$ tolerance, egg-yolk reaction and catalase production. The oxidase test (Kovacs, 1956) was applied to colonies as well as to cell-free extracts. Nitrite tolerance was determined in peptone broth at $\mathrm{pH} 7 \cdot 0$ containing 0.25 to $4 \%(\mathrm{w} / \mathrm{v}) \mathrm{KNO}_{2}$.

Glucose fermentation and oxidation of carbohydrates. For the anaerobic fermentation of glucose, $250 \mathrm{ml}$ flasks containing $50 \mathrm{ml}$ medium II were inoculated from $48 \mathrm{~h}$ nutrient agar cultures and then evacuated. Growth was observed after $6 \mathrm{~d}$. Parallel observations were made in tubes of the semi-solid medium of Hugh \& Leifson (1953) which, after inoculation, were covered with a $3 \mathrm{~cm}$ layer of agar to ensure anaerobiosis. Both procedures yielded the same results. Production of acid from carbohydrates under aerobic conditions was determined by the method of Hugh \& Leifson (1953).

Utilization of organic acids. The medium used contained $\left(\mathrm{g}^{-1}\right): \mathrm{NaCl}, 1 ; \mathrm{MgSO}_{4} .7 \mathrm{H}_{2} \mathrm{O}, 0.2 ; \mathrm{KH}_{2} \mathrm{PO}_{4}, 0.5$; $\mathrm{NH}_{4} \mathrm{Cl}, 0.5$; yeast extract (Difco), 1; agar, 15; organic acid, 2; phenol red, 0.008; pH 6.8, adjusted with 
$1 \mathrm{M}-\mathrm{KOH}$. The medium was dispensed into tubes, autoclaved and used as slopes which were heavily inoculated from $48 \mathrm{~h}$ nutrient agar cultures. Blanks of uninoculated slopes were incubated as well as inoculated controls lacking any organic acid additions. After incubation for 4 to $6 \mathrm{~d}$, positive reactions were indicated by a distinct redness compared with the controls.

Enzyme activities. Anaerobic cultures were grown in 31 flasks containing 11 medium devoid of air. Aerobic cultures were agitated in Fernbach or Erlenmeyer flasks. Cells were harvested after 24 to $48 \mathrm{~h}$ at $32{ }^{\circ} \mathrm{C}$. Nitrate reductases A and B (Pichinoty \& Piéchaud, 1968) and respiratory nitrite reductase (Miyata \& Mori, 1968) were assayed by manometric techniques in extracts of cells grown anaerobically in medium VI. Dehydrogenases for L-glutamate (EC 1.4.1.4), L-alanine (EC 1.4.1.1), and L-leucine (EC 1.4.1.9) were determined spectrophotometrically (Hong et al., 1959; Sanwal \& Zink, 1961) with extracts of cells grown aerobically in medium VII. L-Arginine iminohydrolase (EC 3.5.3.6) activity was measured in these cells (Stanier et al., 1966). $\beta$-Galactosidase (EC 3.2.1.23) was measured (Hestrin et al., 1955) in extracts of cells grown aerobically in medium VII containing $0.4 \%(\mathrm{w} / \mathrm{v})$ lactose.

Enzyme extracts. Cells, grown as described above, were harvested and washed by centrifugation, resuspended in water and disrupted ultrasonically for $2 \mathrm{~min}$ at $0{ }^{\circ} \mathrm{C}$ at $5 \mathrm{~A}$ using an MSE ultrasonic disintegrator. Cell debris was removed by centrifuging at $25000 \mathrm{~g}$ for $10 \mathrm{~min}$ at $4{ }^{\circ} \mathrm{C}$.

Cytochrome spectra. Organisms were cultivated in medium VII aerobically, or anaerobically in the presence of $0.5 \%(\mathrm{w} / \mathrm{v}) \mathrm{KNO}_{3}$ for 24 to $48 \mathrm{~h}$. Reduced-oxidized spectra of the cytochromes in the cell suspensions were obtained in a Cary 15 spectrophotometer at the temperature of liquid nitrogen using Plexiglass cuvettes of $3 \mathrm{~mm}$ light path. Sodium dithionite was added to one cuvette and $\mathrm{H}_{2} \mathrm{O}_{2}$ to the other. Spectra were also obtained at room temperature in the presence of $\mathrm{CO}$ with the addition of dithionite using $10 \mathrm{~mm}$ path length cuvettes.

Denitrification studies. Cultures were grown anaerobically in medium V for $48 \mathrm{~h}$. Reactions were carried out in $125 \mathrm{ml}$ serum bottles containing: cell suspension, $1 \mathrm{ml}$; yeast extract (Difco), $500 \mathrm{mg}$; potassium phosphate buffer pH 7.0, $450 \mu \mathrm{mol}$; chloramphenicol, $2.5 \mathrm{mg} ; \mathrm{KNO}_{3}$ or $\mathrm{KNO}_{2}, 50 \mathrm{mg}$; water, to $25 \mathrm{ml}$; the gaseous phase consisted of $98 \mathrm{ml}$ helium and $2 \mathrm{ml}$ krypton. In some experiments, the $\mathrm{NO}_{3}^{-}{ }^{-}$or $\mathrm{NO}_{2}^{-}$was omitted and $10 \mathrm{ml} \mathrm{NO}$ or $\mathrm{N}_{2} \mathrm{O}$ was added to the gaseous phase. The bottles were agitated in a water bath at $37^{\circ} \mathrm{C}$. Samples of gas $(1 \mathrm{ml})$ were removed at $40 \mathrm{~min}$ intervals over $6 \mathrm{~h}$ and analysed by gas chromatography (Garcia, 1974). Specific activities were calculated from the rates of production or consumption of each gas. These were expressed in $\mu \mathrm{l}\left(22^{\circ} \mathrm{C}\right.$, normal atmospheric pressure) per mg cellular nitrogen per hour. Nitrogen contents of cells were measured by the micro-Kjeldahl method (Bailey, 1967).

Growth studies. Growth was observed for up to $13 \mathrm{~h}$ in conical $1 \mathrm{l}$ flasks containing $450 \mathrm{ml}$ medium IV. For anaerobic cultivation, an over-pressure of about $250 \mathrm{~g}$ was maintained in the stoppered flasks during the experiment and samples were taken through capillary tubes equipped with stopcocks. Cultures were agitated in a water bath. When added, $\mathrm{KNO}_{3}$ or $\mathrm{KNO}_{2}$ were at $0.2 \%(\mathrm{w} / \mathrm{v})$ using $\mathrm{N}_{2}$ as gas. Nitrite production was measured by the assay of Rider \& Mellon (1946) using $1 \mathrm{ml}$ culture added to $3 \mathrm{ml}$ acetone. Other anaerobic cultures were effected under $\mathrm{N}_{2} \mathrm{O}$ or $10 \%(\mathrm{v} / \mathrm{v}) \mathrm{NO}$ in $\mathrm{N}_{2}$. Growth was estimated turbidimetrically at $600 \mathrm{~nm}$ ( $1 \mathrm{~cm}$ light path): an absorbance of 0.5 was equivalent to $220 \mathrm{mg}$ dry wt cells $\mathrm{l}^{-1}$. Aerobic cultures and cultures with NO were inoculated from $24 \mathrm{~h}$ aerobic starter cultures in medium IV; cultures containing $\mathrm{NO}_{3}{ }^{-}$, $\mathrm{NO}_{2}{ }^{-}$or $\mathrm{N}_{2} \mathrm{O}$ were inoculated from anaerobic starters grown with the same electron acceptor. Cell counts were made with a Coulter counter and as colony-forming units on nutrient agar plates.

Base composition of DNA. DNA was extracted and purified by the method of Marmur (1961) from cells grown on medium VII for $12 \mathrm{~h}$ at $32^{\circ} \mathrm{C}$. GC contents were calculated from the buoyant densities in $\mathrm{CsCl}$ by analytical ultracentrifugation relative to an internal reference standard of DNA from bacteriophage $2 \mathrm{C}$ $\left(\rho_{\mathrm{CsCl}}=1.742 \mathrm{~g} \mathrm{~cm}^{-3}\right)$ (Mandel et al., 1968; Schildkraut et al., 1962).

\section{RESULTS}

\section{Isolation}

Although pasteurization was not initially practised, inoculated vessels in later experiments were held at $80^{\circ} \mathrm{C}$ for $10 \mathrm{~min}$ to eliminate non-spore-forming bacteria. Fifteen cultures designated RS1 to RS15 were isolated from different soil sources (Table 1). They have been maintained on nutrient agar slopes and lyophilized samples of each are conserved at the Collection of the Pasteur Institute (Table 1).

\section{Morphology}

Isolated bacteria were all rods $(1.5$ to $7 \cdot 0 \times 0.4$ to $0.5 \mu \mathrm{m})$ with rounded ends giving variable Gram-staining. Motility was difficult to observe in wet mounts. Those cultures which 
Table 1. Origin and some properties of the strains isolated from Senegalese soils

\begin{tabular}{|c|c|c|c|c|c|}
\hline Strain & Origin of the soil (locality; region) & $\begin{array}{l}\text { Maximum } \\
\text { growth } \\
\text { temp. } \\
\left({ }^{\circ} \mathrm{C}\right)\end{array}$ & $\begin{array}{c}\text { Tolerance } \\
\text { to } \mathrm{NO}_{2}^{-} \\
(\mathrm{mM})\end{array}$ & $\begin{array}{c}\mathrm{GC} \\
(\mathrm{mol} \%)\end{array}$ & $\begin{array}{c}\text { CIP* } \\
\text { accession } \\
\text { no. }\end{array}$ \\
\hline RS1 & Loudia; Casamance & 41 & 117 & $40 \cdot 8$ & R902 \\
\hline RS2 & Boundoum; river region & 41 & 117 & $40 \cdot 3$ & R903 \\
\hline RS3 & Bambato; Casamance & 42 & 117 & $39 \cdot 8$ & R904 \\
\hline RS4 & Tanaff; Casamance & 41 & 117 & $39 \cdot 8$ & R905 \\
\hline RS5 & Oussouye; Casamance & 41 & 117 & $41 \cdot 3$ & R906 \\
\hline RS6 & Djibelor; Casamance & 41 & 117 & $40 \cdot 8$ & R907 \\
\hline RS7 & Djibelor; Casamance & 42 & 117 & $40 \cdot 8$ & R908 \\
\hline RS8 & Sébikotane; Cap-Vert & 41 & 117 & $41 \cdot 5$ & R909 \\
\hline RS9 & Keur-Diallo; river region & 42 & 59 & $40 \cdot 3$ & R899 \\
\hline RS10 & Diango; Casamance & 43 & 411 & $39 \cdot 5$ & R895 \\
\hline RS11 & Bounkilinn; Casamance & 41 & 294 & $40 \cdot 8$ & $\mathbf{R} 896$ \\
\hline RS12 & Ntiagar; river region & 45 & 411 & $39 \cdot 1$ & R897 \\
\hline RS13 & River region & 44 & 411 & $39 \cdot 1$ & R898 \\
\hline RS14 & Boundoum Dam; river region & 42 & 117 & $41 \cdot 3$ & R900 \\
\hline RS15 & M'Bang; river region & 45 & 353 & $41 \cdot 3$ & R901 \\
\hline
\end{tabular}

* CIP, Collection de l'Institut Pasteur.

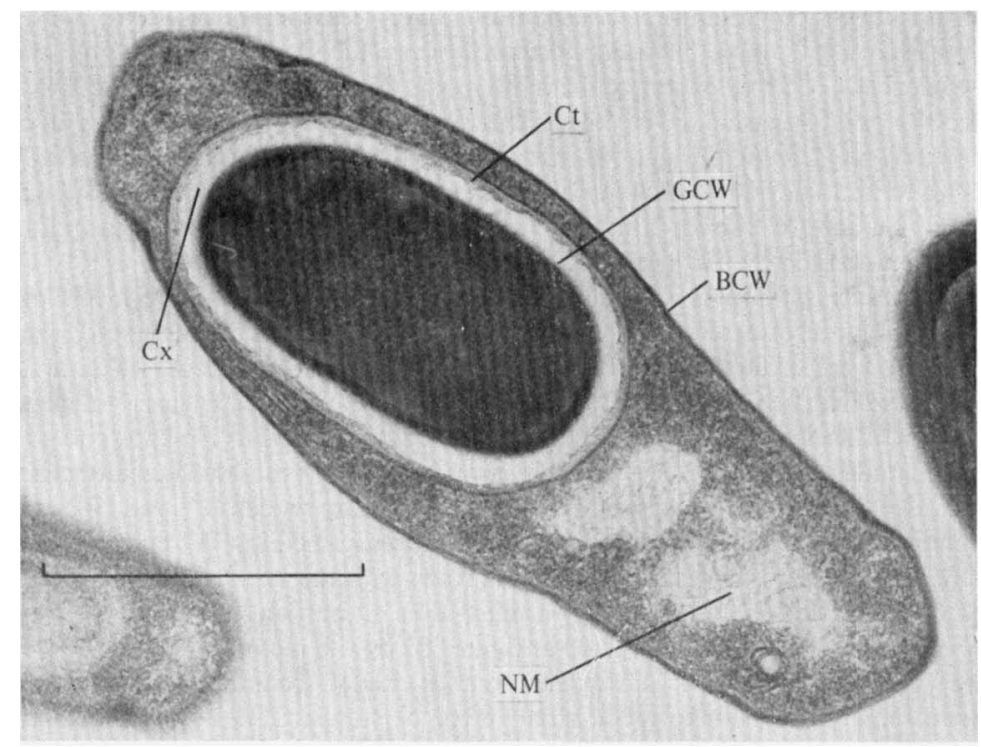

Fig. 1. Ultrathin section of a strain RS5 cell with an endospore: BCW, bacterial cell wall; NM, nuclear material; $\mathrm{Ct}$, spore coat; $\mathrm{Cx}$, cortex; GCW, germ cell wall. Bar marker represents $1 \mu \mathrm{m}$.

were motile had only a few flagella arranged peritrichously. Ultrathin sections of cells of strain RS5 showed a somewhat thin cell wall structure characteristic of Gram-positive bacteria (Fig. 1). Endospores $(1 \cdot 1 \times 0.6$ to $0.8 \mu \mathrm{m})$ were oval, distinctly bulged the sporangium and had the typical structure of endospores of Bacillus, though with a thinner spore coat. Capsules were never observed.

Growth of isolates in liquid medium was without pellicle formation. Colonies on solid medium varied in appearance according to age. On nutrient agar, colonies of RS10, RS12, RS13, RS14 and RS15 were convex and translucent (Fig. $2 a$ ); colonies of the other strains were circular and convex with opaque centres and translucent margins (Fig. 2b) except RS11 which was pale yellow and entirely opaque. 

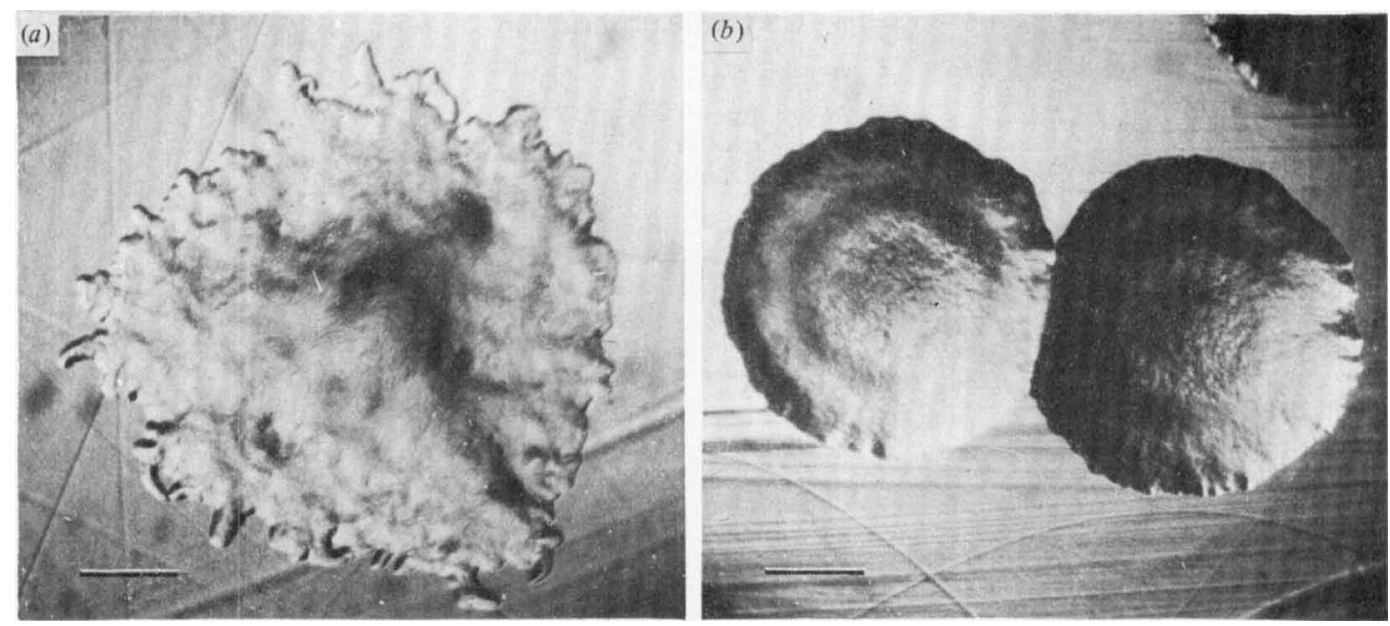

Fig. 2. Colonies of strains RS13 (a) and RS8 (b) on nutrient agar. Bar markers represent $1 \mathrm{~mm}$.

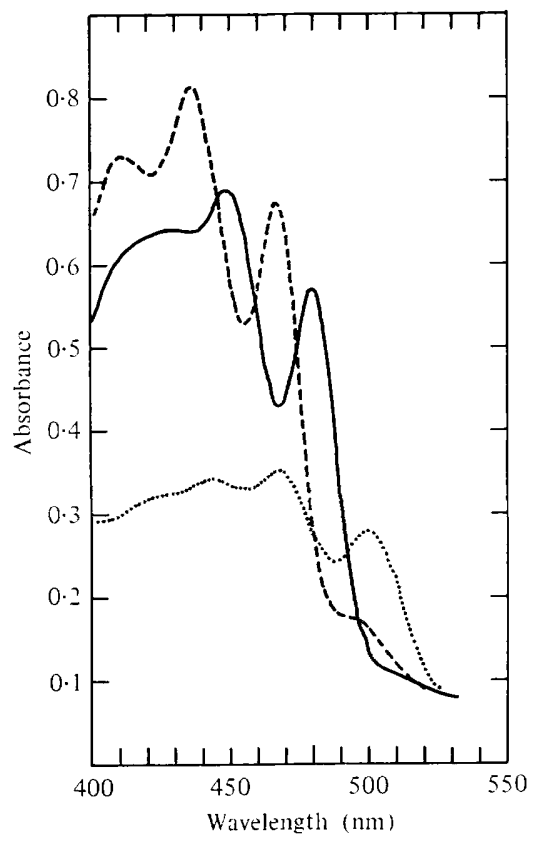

Fig. 3. Absorption spectra of the carotenoid pigment of strain RS9 in benzene ( $\longrightarrow$ ), petroleum ether $(--)$ and carbon disulphide $(\cdots)$.

\section{Properties of the intracellular pigment of strain RS9}

Centrifuged pellets of cells of strain RS9 were yellow, though the colour was not seen in colonies. Portions of the cell mass turned blue when suspended in $50 \%(\mathrm{v} / \mathrm{v}) \mathrm{H}_{2} \mathrm{SO}_{4}$ suggesting the presence of a carotenoid (Skerman, 1967). Spectra are shown in Fig. 3. The pigment exhibited major absorption peaks at 407, 436 and $464 \mathrm{~nm}$ in methanol, 427, 448 and $479 \mathrm{~nm}$ in benzene, 411,437 and $467 \mathrm{~nm}$ in petroleum ether and 420, 443, 468 and 501 $\mathrm{nm}$ in carbon disulphide; these are characteristic of carotenoids (Liaaen-Jensen \& Jensen, 1971; Weedon, 1965). 
Table 2. Variable characters

Total
no. of
positive
strains

Motility and presence of flagella

Growth on $\mathrm{N}_{2} \mathrm{O}$

Growth on NO

Fermentation of glucose

Growth in the presence of $5 \%(w / v) ~ N a C l$

Growth in the presence of $8 \%(\mathrm{w} / \mathrm{v}) \mathrm{KNO}_{3}$

Growth at $\mathrm{pH} 5 \cdot 6$

Nitrate reductase $\mathrm{A}$

Unidentified nitrate reductase

Production of a brown pigment in media

containing tyrosine

Hydrolysis of:

Hippurate

Gelatin

Starch

Tween 80

Urea

$\beta$-Galactosidase

Arginine iminohydrolase

L-Glutamate dehydrogenase

Egg-yolk reaction

Production of a yellow pigment

Total
no. of
positive
strains

13 RS3, RS14

12 RS7, RS9, RS14

7 RS7, RS9, RS10, RS11, RS12, RS13, RS14, RS15

9 RS10, RS11, RS12, RS13, RS14, RS15

6 All except RS7, RS10, RS11, RS12, RS13, RS15

12 RS7, RS8, RS9

1 All except RS14

1 All except RS15

14 RS15

3 All except RS10, RS12, RS13

5 All except RS7, RS11, RS12, RS14, RS15

3 All except RS9, RS11, RS14

2 All except RS9, RS11

11 RS10, RS11, RS12, RS13

4 All except RS7, RS11, RS13, RS14

10 RS10, RS12, RS13, RS14, RS15

3 All except RS6, RS8, RS11

14 RS9

1 All except RS5

1 All except RS9

\section{Physiological characters}

All 15 cultures were facultative anaerobes, grew anaerobically in medium VII containing $0.5 \%(\mathrm{w} / \mathrm{v}) \mathrm{KNO}_{3}$ or $0.2 \%(\mathrm{w} / \mathrm{v}) \mathrm{KNO}_{2}$ and produced $\mathrm{N}_{2}$. Anaerobic growth did not occur in this medium if $0.2 \%(\mathrm{w} / \mathrm{v}) \mathrm{K}_{2} \mathrm{~S}_{4} \mathrm{O}_{6}, \mathrm{Na}_{2} \mathrm{~S}_{2} \mathrm{O}_{3}$ or sodium fumarate replaced the $\mathrm{NO}_{3}{ }^{-}$or $\mathrm{NO}_{2}^{-}$.

Growth at the expense of NO was studied in $250 \mathrm{ml}$ flasks containing $50 \mathrm{ml}$ medium III or IV with an atmosphere of $10 \% \mathrm{NO}$ in $\mathrm{N}_{2}$ and sealed with silicone rubber stoppers. The results are presented in Table 2 . In medium III, limited anaerobic growth under $100 \% \mathrm{~N}_{2}$ was obtained by the fermentation of the carbohydrates present in the yeast extract and consequently medium IV was preferred for this evaluation. The eight cultures listed in Table 2 as not growing in the presence of NO did not do so even if the medium was supplemented with $0.5 \%$ (w/v) $\mathrm{KNO}_{3}$.

All cultures were oxidase positive, possessed cytochrome $c$ and catalase (EC 1.11.1.6). All required accessory growth factors (which have not been identified). None grew in peptone media containing $0.02 \%(\mathrm{w} / \mathrm{v}) \mathrm{NaN}_{3}$ or $0.001 \%$ (w/v) lysozyme (EC 3.2.1.17), nor did any synthesize poly- $\beta$-hydroxybutyrate. None decomposed tyrosine, produced indole or acetylmethylcarbinol. Dihydroxyacetone was not produced from glycerol. Brown or black pigments were never observed on glucose-containing media. L-Phenylalanine deaminase was absent but L-alanine dehydrogenase, L-leucine dehydrogenase and respiratory nitrite reductase were present. Cultures able to ferment glucose did not produce $\mathrm{H}_{2}$.

The maximum growth temperature in peptone broth was between 41 and $45^{\circ} \mathrm{C}$. All the cultures tolerated at least $59 \mathrm{mM}-\mathrm{NO}_{2}{ }^{-}$and some tolerated almost sevenfold higher concentrations (Table 1). Additional features which varied amongst the 15 cultures are presented in Table 2.

The nine cultures having fermentative activity (Table 2) grew slowly on glucose anaerobically and slightly acidified the medium. Seven carbohydrates (L-rhamnose, L-sorbose, D-melibiose, D-dulcitol, D-arabitol, aesculin and meso-erythritol) were not oxidized by any culture. Twenty-five other carbohydrates were oxidized by some, but not all, of the 15 
Table 3. Acid production from carbohydrates

\begin{tabular}{|c|c|c|}
\hline Substrate & $\begin{array}{c}\text { Total } \\
\text { no. of } \\
\text { positive } \\
\text { strains }\end{array}$ & Negative strains \\
\hline D-Glucose & 14 & RS15 \\
\hline D-Mannose & 8 & RS7, RS10, RS11, RS12, RS13, RS14, RS15 \\
\hline D-Fructose & 12 & RS12, RS13, RS15 \\
\hline D-Galactose & 9 & RS9, RS10, RS12, RS13, RS14, RS15 \\
\hline L-Fucose & 1 & All except RS11 \\
\hline D-Fucose & 1 & All except RS14 \\
\hline Cellobiose & 8 & RS9, RS10, RS11, RS12, RS13, RS14, RS15 \\
\hline Maltose & 14 & RS15 \\
\hline Lactose & 3 & All except RS7, RS9, RS11 \\
\hline D-Trehalose & 12 & RS12, RS13, RS15 \\
\hline Sucrose & 7 & RS3, RS7, RS8, RS10, RS12, RS13, RS14, RS15 \\
\hline Salicin & 8 & RS7, RS10, RS11, RS12, RS13, RS14, RS15 \\
\hline Raffinose & 5 & All except RS1, RS2, RS3, RS5, RS6 \\
\hline D-Melezitose & 8 & RS9, RS10, RS11, RS12, RS13, RS14, RS15 \\
\hline D-Xylose & 8 & RS7, RS9, RS10, RS12, RS13, RS14, RS15 \\
\hline D-Ribose & 14 & RS15 \\
\hline L-Arabinose & 6 & All except RS1, RS2, RS3, RS4, RS5, RS8 \\
\hline D-Arabinose & 1 & All except RS11 \\
\hline$\alpha$-Methyl-D-glucoside & 6 & All except RS1, RS2, RS4, RS5, RS6, RS9 \\
\hline D-Gluconate & 6 & All except RS2, RS3, RS5, RS6, RS9, RS10 \\
\hline D-Sorbitol & 5 & All except RS1, RS3, RS5, RS6, RS8 \\
\hline D-Mannitol & 10 & RS9, RS12, RS13, RS14, RS15 \\
\hline L-Arabitol & 1 & All except RS14 \\
\hline Arbutin & 1 & All except RS 9 \\
\hline Glycerol & 14 & RS9 \\
\hline
\end{tabular}

cultures (Table 3). Culture RS15 was readily distinguished from all others by its inability to oxidize any carbohydrate except glycerol.

Of 24 organic acids tested, only pyruvate and $\mathrm{L}$-asparagine were oxidized by all isolates; propionate was oxidized by none. The reactions with respect to the remaining 21 compounds are given in Table 4.

Two bacterial nitrate reductases $\mathrm{A}$ and $\mathrm{B}$ are known and can be distinguished by their activity with chlorate which serves as substrate for nitrate reductase A but inhibits enzyme B (Pichinoty \& Piéchaud, 1968). For 14 isolates, chlorate served neither as substrate nor inhibitor; hence an unidentified nitrate reductase activity is presumed. In cell-free extracts of strain RS5, $96 \%$ of this nitrate reductase activity was recovered in the pellet after centrifuging at $140000 \mathrm{~g}$ for $2 \mathrm{~h}$.

\section{DNA base compositions}

The GC content of the DNA of each isolate is given in Table 1. The mean of all the analyses was $40 \cdot 4 \pm 0 \cdot 8 \mathrm{~mol} \% \mathrm{GC}$.

\section{Cytochrome spectra}

Components of the respiratory chain were identified in cells grown aerobically. The absorption peaks for cytochromes $b, c$ and $a$ at liquid nitrogen temperature were not significantly different in the various cultures though the relative intensities of the peaks characteristic of each protein did vary. Two cytochrome oxidases were observed: $a+a_{3}$, with an absorption maximum at 600 to $602 \mathrm{~nm}$, and the CO-binding pigment (cytochrome $o$ ), whose Soret band was at 415 to $418 \mathrm{~nm}$ at room temperature. Some doubt nevertheless must 
Table 4. Organic acids utilized for growth

\begin{tabular}{|c|c|c|}
\hline Substrate & $\begin{array}{c}\text { Total } \\
\text { no. of } \\
\text { positive } \\
\text { strains }\end{array}$ & Negative strains \\
\hline Acetate & 14 & RS8 \\
\hline Butyrate & 8 & RS1, RS4, RS6, RS10, RS11, RS12, RS14 \\
\hline Isobutyrate & 9 & RS1, RS3, RS4, RS5, RS8, RS13 \\
\hline Valerate & 1 & All except RS10 \\
\hline Isovalerate & 5 & All except RS7, RS10, RS11, RS14, RS15 \\
\hline DL-Lactate & 11 & RS9, RS10, RS12, RS13 \\
\hline DL- $\beta$-Hydroxybutyrate & 9 & RS1, RS3, RS11, RS12, RS13, RS14 \\
\hline Glycollate & 3 & All except RS10, RS11, RS14 \\
\hline Succinate & 4 & All except RS2, RS7, RS9, RS15 \\
\hline L-Malate & 9 & RS1, RS4, RS5, RS6, RS10, RS13 \\
\hline Fumarate & 6 & All except RS1, RS2, RS7, RS9, RS14, RS15 \\
\hline Citrate & 3 & All except RS7, RS11, RS14 \\
\hline$\alpha$-Ketoglutarate & 11 & RS1, RS2, RS3, RS5 \\
\hline Malonate & 3 & All except RS5, RS7, RS8 \\
\hline Glutarate & 2 & All except RS11, RS15 \\
\hline Tartrate & 1 & All except RS15 \\
\hline Glycine & 10 & RS3, RS4, RS5, RS6, RS14 \\
\hline L- $\alpha$-Alanine & 14 & RS14 \\
\hline DL-Aspartate & 11 & RS1, RS4, RS5, RS12 \\
\hline L-Glutamate & 11 & RS3, RS4, RS6, RS14 \\
\hline L-Glutamine & 3 & All except RS11, RS12, RS15 \\
\hline
\end{tabular}

Table 5. Rates of reduction of nitrogen oxides by cell suspensions of strains RS3 and RS14 Evolution and consumption of gas are expressed as $\mu \mathrm{l}(\mathrm{mg} \mathrm{N})^{-1} \mathrm{~h}^{-1}$.

\begin{tabular}{|c|c|c|c|c|c|c|c|c|c|c|c|}
\hline \multirow[b]{3}{*}{ Culture conditions } & \multirow{3}{*}{$\begin{array}{l}\text { Electron } \\
\text { acceptor }\end{array}$} & \multicolumn{5}{|c|}{ Strain RS3 } & \multicolumn{5}{|c|}{ Strain RS14 } \\
\hline & & \multicolumn{3}{|c|}{ Evolution } & \multicolumn{2}{|c|}{ Consumption } & \multicolumn{3}{|c|}{ Evolution } & \multicolumn{2}{|c|}{ Consumption } \\
\hline & & No & $\mathrm{N}_{2} \mathrm{O}$ & $\mathrm{N}_{2}$ & No & $\mathrm{N}_{2} \mathrm{O}$ & NO & $\mathrm{N}_{2} \mathrm{O}$ & $\mathrm{N}_{2}$ & NO & $\mathrm{N}_{2} \mathrm{O}$ \\
\hline $\begin{array}{l}\text { Anaerobic, containing } \\
\mathrm{NO}_{3}^{-}\end{array}$ & $\begin{array}{l}\mathrm{NO}_{3}^{-} \\
\mathrm{NO}_{2}^{-} \\
\mathrm{NO} \\
\mathrm{N}_{2} \mathrm{O}\end{array}$ & $\begin{array}{l}0 \\
0 \\
-\end{array}$ & $\begin{array}{l}0 \\
0 \\
0 \\
-\end{array}$ & $\begin{array}{r}146 \\
291 \\
174 \\
2287\end{array}$ & $\begin{array}{c}- \\
295 \\
-\end{array}$ & $\begin{array}{r}\overline{-} \\
\overline{2349}\end{array}$ & $\begin{array}{l}0 \\
0 \\
- \\
-\end{array}$ & $\begin{array}{r}0 \\
0 \\
0 \\
-\end{array}$ & $\begin{array}{r}70 \\
92 \\
144 \\
1198\end{array}$ & $\frac{\overline{-}}{304}$ & $\begin{array}{r}\overline{-} \\
\overline{1168}\end{array}$ \\
\hline $\begin{array}{l}\text { Anaerobic, containing } \\
\mathrm{NO}_{2}^{-}\end{array}$ & $\begin{array}{l}\mathrm{NO}_{3}^{-} \\
\mathrm{NO}_{2}^{-} \\
\mathrm{NO}^{-} \\
\mathrm{N}_{2} \mathrm{O}\end{array}$ & $\begin{array}{l}0 \\
0 \\
- \\
-\end{array}$ & $\begin{array}{r}242 \\
251 \\
0 \\
-\end{array}$ & $\begin{array}{r}342 \\
519 \\
445 \\
2626\end{array}$ & $\begin{array}{c}- \\
604 \\
-\end{array}$ & $\frac{-}{-}$ & $\begin{array}{l}0 \\
0 \\
- \\
-\end{array}$ & $\begin{array}{l}0 \\
0 \\
0 \\
-\end{array}$ & $\begin{array}{r}493 \\
1030 \\
230 \\
2351\end{array}$ & $\frac{\bar{z}}{\overline{443}}$ & $\frac{-}{2541}$ \\
\hline
\end{tabular}

remain as to the true identity of this cytochrome $o$ as the photochemical action spectrum (Lemberg \& Barrett, 1973) has not been obtained. Also observed were cytochrome $c$, whose $\alpha$ peak was at 547 to $549 \mathrm{~nm}$, and possibly two or even three cytochromes $b$, with $\alpha$ peaks between 551 and $564 \mathrm{~nm}$.

Strains RS3, RS7, RS12 and RS15, when cultivated anaerobically in the presence of $\mathrm{NO}_{3}{ }^{-}$, all possessed cytochromes $c$ and $o$. In contrast, the cytochrome oxidase $a+a_{3}$ was absent from all and only a single cytochrome $b$ was visible in each. There was no peak of absorption between 625 and $630 \mathrm{~nm}$ which would be characteristic of cytochrome $d_{1} c$ which catalyses the reduction of $\mathrm{NO}_{2}^{-}$to $\mathrm{NO}$ and thus functions as a respiratory nitrite reductase in many different non-sporulating denitrifying bacteria (Miyata \& Mori, 1968).

\section{Denitrification by cell suspensions}

Culture RS3 was selected as representative of those strains which grew with $\mathrm{NO}$ or $\mathrm{N}_{2} \mathrm{O}$ as terminal electron acceptors and culture RS14 as representative of those which responded 


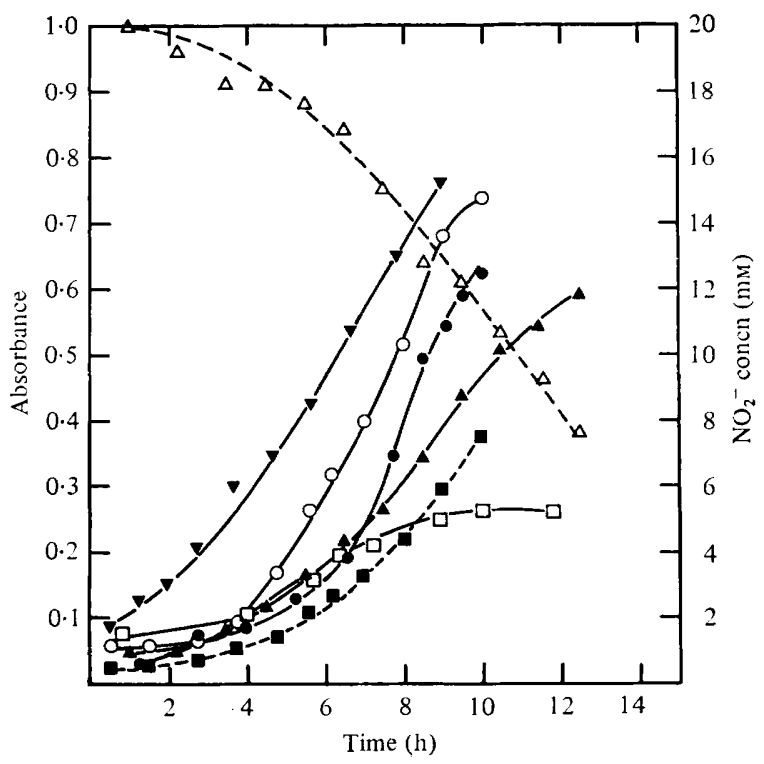

Fig. 4. Growth of strain RS1 at $37^{\circ} \mathrm{C}$ and strain RS8 at $32{ }^{\circ} \mathrm{C}$ in medium IV in the presence of different electron acceptors. Strain RS1: $\mathbf{\nabla}$, growth on air; $\bigcirc$, growth on $\mathrm{NO}_{3}{ }^{-}$under a $\mathrm{N}_{2}$ atmosphere; $\mathbf{\square}$, production of $\mathrm{NO}_{2}{ }^{-}$during growth on $\mathrm{NO}_{3}^{-} ; \boldsymbol{\Delta}$, growth on $\mathrm{NO}_{2}^{-}$under a $\mathrm{N}_{2}$ atmosphere; $\triangle$, reduction of $\mathrm{NO}_{2}{ }^{-}$during growth on $\mathrm{NO}_{2}{ }^{-} ; \boldsymbol{O}$, growth on $\mathrm{N}_{2} \mathrm{O}$. Strain RS8: $\square$, growth on $10 \%$ NO in $\mathrm{N}_{2}$.

to neither of these gases (Table 2). Activities of the cell suspensions cultivated anaerobically on $\mathrm{NO}_{2}^{-}$or $\mathrm{NO}_{3}{ }^{-}$are shown in Table $5 . \mathrm{N}_{2} \mathrm{O}$ was more rapidly reduced than $\mathrm{NO}$ by both cultures, irrespective of whether $\mathrm{NO}_{3}{ }^{-}$or $\mathrm{NO}_{2}{ }^{-}$served as electron acceptor during growth. The stoicheiometries were as expected, 1 mol $\mathrm{N}_{2} \mathrm{O}$ yielding $1 \mathrm{~mol} \mathrm{~N}_{2}$, and $2 \mathrm{~mol} \mathrm{NO}$ yielding $1 \mathrm{~mol} \mathrm{~N}$. Cells grown in the presence of $\mathrm{NO}_{2}-$ denitrified $\mathrm{NO}_{3}{ }^{-}$.

\section{Growth in the presence of various electron acceptors}

Growth curves are shown in Fig. 4. When NO served as the electron acceptor, a growth lag of from 40 to $60 \mathrm{~h}$ was always observed (not shown). Though this lag might be due to the selection of mutants resistant to the toxic action of NO, this was not so as cultures grown in the presence of NO did not show a shorter lag when inoculated into fresh medium; independent clones of RS8 on nutrient agar from a culture grown in $10 \%$ NO displayed the same lag as the parent culture.

Of all the oxidized forms of nitrogen tested as electron acceptors, growth on NO exhibited the longest generation times and lowest growth yield. Microscopically, cells so grown were quite normal - motile strains remained motile; cell viability was somewhat variable, but frequently attained $70 \%$. The gaseous products obtained during growth with NO were examined by gas chromatography. During growth, $\mathrm{N}_{2} \mathrm{O}$ and $\mathrm{N}_{2}$ were produced followed by the disappearance of the $\mathrm{NO}$ and $\mathrm{N}_{2} \mathrm{O}$ which were completely reduced to $\mathrm{N}_{2}$ in a few days. Uninoculated media with NO in the atmosphere did not produce these gases, showing that reduction of NO was a biological process.

\section{Cultivation of diverse denitrifying species in the presence of $N O$}

The 70 denitrifying bacteria examined tolerated relatively high $\mathrm{NO}_{2}^{-}$- concentrations but none of them grew in medium III at $32{ }^{\circ} \mathrm{C}$ under $10 \% \mathrm{NO}$ in $\mathrm{N}_{2}$, even if the medium contained $0.5 \%(\mathrm{w} / \mathrm{v}) \mathrm{KNO}_{3}$. 


\section{Alteration of medium IV by NO}

NO is an active oxidant and reacts slowly with components of medium IV to lessen its nutritive value: when $250 \mathrm{ml}$ glass-stoppered flasks containing $50 \mathrm{ml}$ medium and an atmosphere of $50 \%$ NO in $\mathrm{N}_{2}$ were sealed for 1 week at $32{ }^{\circ} \mathrm{C}$, the medium became acidic and turned pink, and when such flasks were seeded with garden soil and incubated aerobically at $32{ }^{\circ} \mathrm{C}$, they showed no growth over several weeks. Thus NO cannot be used for direct enrichment of organisms capable of using it as terminal electron acceptor.

\section{DISCUSSION}

The bacteria described were an assemblage of heterogeneous phenotypes. It may be fortuitous that the GC contents of their DNAs showed little variation. All had common morphological features and had some characters of Bacillus brevis: oxidase and catalase positive and ability to reduce $\mathrm{NO}_{3}{ }^{-}$to $\mathrm{NO}_{2}{ }^{-}$; six of the cultures were also incapable of fermenting carbohydrates (De Barjac \& Bonnefoi, 1972; Gibson \& Gordon, 1974; Gordon et al., 1973). Nevertheless, B. brevis cannot denitrify and has a higher GC content in its DNA (Gibson \& Gordon, 1974; Pichinoty et al., 1978a). Five cultures of $B$. brevis erroneously reported as denitrifiers by Gordon et al. (1973) are incapable of anaerobic growth in the presence of $\mathrm{NO}_{3}{ }^{-}, \mathrm{NO}_{2}^{-}$or $\mathrm{N}_{2} \mathrm{O}$ (Pichinoty et al., 1978a).

Bacillus azotoformans, which also belongs to the same morphological group, is distinguished from the 15 cultures described here in many ways: colonial morphology, failure to retain the Gram-stain, very active motility with numerous flagella, poly- $\beta$-hydroxybutyrate synthesis, utilization of tetrathionate and fumarate as electron acceptors and failure to decompose $\mathrm{H}_{2} \mathrm{O}_{2}$ (Pichinoty et al., 1976b, 1978a).

The new isolates could not be identified using existing schemes, but we make no taxonomic proposals until more strains have been isolated and examined.

The absence of a peak between 625 and $630 \mathrm{~nm}$ does not prove the absence of cytochrome $d_{1} c$. The method employed may not have been sufficiently sensitive to detect it.

The inability of culture RS14 to grow at the expense of $\mathrm{N}_{2} \mathrm{O}$ or NO could not be explained by any enzymic deficiency since the reductases for both substrates were clearly evident. This bacterium was inhibited by $\mathrm{NO}$ gas. Inability to grow on $\mathrm{N}_{2} \mathrm{O}$ must have some other explanation, because this gas is not toxic.

The seven cultures growing in the presence of NO fermented glucose, but one culture (RS9) which fermented glucose could not utilize NO.

It was possible that NO was not used directly as electron acceptor, but rather reacted with one or more organic medium components and was thus converted to a more tractable electron acceptor. This seems unlikely for the following reasons: all denitrifying bacteria appear to possess a nitric oxide reductase (Payne, 1973; Pichinoty, 1973); reduction of NO by cell suspensions was rapid with no indication of a latent phase. Resistance to high concentrations of $\mathrm{NO}_{2}^{-}$and to NO suggests that these toxic and mutagenic compounds are reduced at the cell boundary and do not penetrate to the cytoplasm. Nitrate reductase of Escherichia coli has such a location (Haddock \& Jones, 1977), but the locations of nitrite and nitric oxide reductases in denitrifying bacteria are not yet known.

Growth with NO as terminal electron acceptor is an exceptional property of 7 of the 15 cultures isolated from the Senegalese soils, suggesting that this oxide of nitrogen (which is found in vitro in the course of the reduction of nitrite by nitrite reductase) is an intermediate in denitrification (Miyata \& Mori, 1968; Payne, 1973; Pichinoty, 1973). The 70 collection strains and 8 of the 15 strains described could not grow in the presence of NO.

Biological reduction of NO could occur in situ; the chemical decomposition of $\mathrm{NO}_{2}^{-}$has been observed in various soils (acid and neutral as well as alkaline) with production of this gas (Bulla et al., 1970). Knowledge of soil bacteria is limited and new isolation procedures 
regularly reveal new isolates whose form and function often modify our understanding of the soil microflora. Enrichment cultures will be made using soils of temperate regions in order to determine whether the bacteria described here are specific to tropical soils.

We are grateful to Dr A. Ryter (Institut Pasteur, Paris, France) for the preparation of the electron micrograph.

\section{REFERENCES}

Batley, J. L. (1967). Techniques in Protein Chemistry, 2nd edn, pp. 346-347. London \& New York: Elsevier.

Broadbent, F. E. \& Clark, F. (1965). Denitrification. In Soil Nitrogen, pp. 344-359. Edited by W. V. Bartholomew \& F. E. Clark. Madison: American Society of Agronomy.

Bulla, L. A., Gilmour, C. M. \& Bollen, W. B. (1970). Non-biological reduction of nitrite in soil. Nature, London 225, 664.

DE BARJAC, H. \& Bonnefor, A. (1972). Essai de classification biochimique de 64 'Bacillus' des groupes II et III représentant 11 espèces différentes. Annales de l'Institut Pasteur 122, 463-473.

Garcia, J.-L. (1974). Réduction de l'oxyde nitreux dans les sols de rizières du Sénégal: mesure de l'activité dénitrifiante. Soil Biology and Biochemistry 6, 79-84.

Garcia, J.-L., Pichinoty, F., Mandel, M. \& GreENWAY, B. (1977). A new denitrifying saprophyte related to Pseudomonas pickettii. Annales de Microbiologie 128A, 229-237.

Gibson, T. \& Gordon, R. E. (1974). Genus 1. Bacillus Cohn 1872, 174; nom.gen.cons. Nomencl. Comm. Intern. Soc. Microbiol. 1937, 28; Opin. A. Jud. Comm. 1955, 39. In Bergey's Manual of Determinative Bacteriology, 8th edn, pp. 529-550. Edited by R. E. Buchanan \& N.E. Gibbons. Baltimore: Williams \& Wilkins.

Gordon, R. E., Haynes, W. C. \& Pang, C. H.-N. (1973). The genus Bacillus. Agriculture Handbook No. 427. Washington: United States Department of Agriculture.

HadDock, B. A. \& Jones, C. W. (1977). Bacterial respiration. Bacteriological Reviews 41, 47-99.

Hestrin, S., Feingold, D. S. \& Schramm, M. (1955). Hexoside hydrolases. Methods in Enzymology 1, 231-257.

Hong, M. M., Shen, S. C. \& Braunstein, A. E. (1959). Distribution of L-alanine dehydrogenase and L-glutamate dehydrogenase in bacilli. Biochimica et biophysica acta 36, 288-289.

Hugh, R. \& Leifson, E. (1953). The taxonomic significance of fermentative versus oxidative metabolism of carbohydrates by various Gram negative bacteria. Journal of Bacteriology 66, $24-26$.

Kovacs, N. (1956). Identification of Pseudomonas pyocyanea by the oxidase reaction. Nature, London 178, 703.

LAW, J. H. \& SLEPECKY, R. A. (1961). Assay of poly- $\beta$-hydroxybutyric acid. Journal of Bacteriology 82, 33-36.

LemBerg, R. \& BARRetT, J. (1973). Bacterial cytochromes and cytochrome oxidases. In Cytochromec, pp. 217-326. London \& New York: Academic Press.
LiaAen-Jensen, S. \& Jensen, A. (1971). Quantitative determination of carotenoids in photosynthetic tissues. Methods in Enzymology, 23A, 586-602.

Mandel, M., Schildkraut, C. L. \& Marmur, J. (1968). Use of $\mathrm{CsCl}$ density gradient analysis for determining the guanine plus cytosine content of DNA. Methods in Enzymology, 12B, 184-195.

MARMUR, J. (1961). A procedure for the isolation of deoxyribonucleic acid from micro-organisms. Journal of Molecular Biology 3, 208-218.

Miyata, M. \& MORI, T. (1968). Studies on denitrification. VIII. Production of nitric oxide by denitrifying reaction in the presence of tetramethyl-p-phenylenediamine. Journal of Biochemistry 64, 849-861.

Payne, W. J. (1973). Reduction of nitrogenous oxides by microorganisms. Bacteriological Reviews 37, 409-452.

Pichinoty, F. (1973). La réduction bactérienne des composés oxygénés minéraux de l'azote. Bulletin de l'Institut Pasteur, Paris 71, 317-395.

Pichinoty, F. \& Piéchaud, M. (1968). Recherche des nitrate-réductases bactériennes $\mathrm{A}$ et $\mathrm{B}$ : méthodes. Annales de l'Institut Pasteur 114, 7798,

Pichinoty, F., Bigliardi-Rouvier, J., Mandel, M., Greenway, B., Méténier, G. \& Garcia, J.-L. (1976a). The isolation and properties of a denitrifying bacterium of the genus Flavobacterium. Antonie van Leeuwenhoek 42, 349-354.

Pichinoty, F., de BarJac, H., Mandel, M., Greenway, B. \& Garcia, J.-L. (1976b). Une nouvelle bactérie sporulée, dénitrifiante, mésophile: Bacillus azotoformans n.sp. Annales de Microbiologie 127B, 351-361.

Pichinoty, F., Mandel, M. \& Garcia, J.-L. (1977a). Etude de six souches de Agrobacterium tumefaciens et $A$. radiobacter. Annales de Microbiologie 128A, 303-310.

Pichinoty, F., Mandel, M. \& Garcia, J.-L. $(1977 b)$. Etude physiologique et taxonomique de Paracoccus denitrificans. Annales de Microbiologie 128B, 243-251.

Pichinoty, F., Mandel, M., Greenway, B. \& Garcia, J.-L. (1977c). Etude de 14 bactéries dénitrifiantes appartenant au groupe Pseudomonas stutzeri isolées du sol par culture d'enrichissement en présence d'oxyde nitreux. Annales de Microbiologie 128A, 75-87.

Pichinoty, F., Mandel, M., Greenway, B. \& Garcia, J.-L. (1977d). Isolation and properties of a denitrifying bacterium related to Pseudomonas lemoignei. International Journal of Systematic Bacteriology 27, 346-348.

Pichinoty, F., Durand, M., Job, C., Mandel, M. \& GARCIA, J.-L. (1978a). Etude morphologique, physiologique et taxonomique de Bacillus azoto- 
formans. Canadian Journal of Microbiology 24. 608-617.

Pichinoty, F., Garcia, J.-L., Job, C. \& Durand, M. (1978b). La dénitrification chez Bacillus licheniformis. Canadian Journal of Microbiology 24, 45-49.

Pichinoty, F., Garcia, J.-L., Mandel, M., Job, C. \& Durand, M. $(1978 c)$. Isolement de bactéries utilisant en anaérobiose l'oxyde nitrique comme accepteur d'électrons respiratoire. Comptes rendus hebdomadaires des séances de l'Académie des Sciences, Série D 286, 1403-1405.

Pichinoty, F., Véron, M., Mandel, M., Durand, M., Job, C. \& Garcia, J.-L. (1978d). Etude physiologique et taxonomique du genre Alcaligenes: $A$. denitrificans $A$. odorans et $A$. faecalis. Canadian Journal of Microbiology 24, 743-753.

RHodes, M. E. (1958). The cytology of Pseudomonas spp. as revealed by a silver-plating staining method. Journal of General Microbiology 18, 639-648.

Rider, B. F. \& Mellon, M. G. (1946). Colorimetric determination of nitrites. Industrial and Engineering Chemistry 18, 96-99.
Sanwal, B. D. \& ZINK, M. W. (1961). L-Leucine dehydrogenase of Bacillus cereus. Archives of Biochemistry and Biophysics 94, 430-435.

Schildkraut, C. L., Marmur, J. \& Doty, P. (1962). Determination of the base composition of deoxyribonucleic acid from its buoyant density in CsCl. Journal of Molecular Biology 4, 430-433.

Skerman, V. B. D. (1967). A Guide to the Identifcation of the Genera of Bacteria, 2nd edn. Baltimore: Williams \& Wilkins.

Stanier, R. Y., Palleroni, N. J. \& Doudoroff, M. (1966). The aerobic pseudomonads: a taxonomic study. Journal of General Microbiology 43, 159-271.

VERHOEVEN, W. (1952). Aerobic sporeforming nitrate reducing bacteria. Thèse. Delft: Uitgeverij Waltman.

WeEDON, B. C. L. (1965). Chemistry of the carotenoids. In Chemistry and Biochemistry of Plant Pigments, pp. 75-125. Edited by T. W. Goodwin. London \& New York: Academic Press. 